


\section{BUKU AJAR FUNGSI KHUSUS}

Emas Marlina, S.Pd.,M.Pd

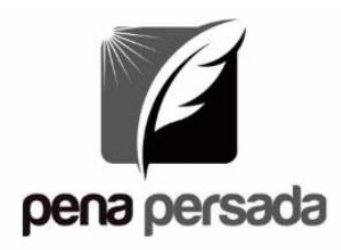

PENERBIT CV. PENA PERSADA 


\title{
BUKU AJAR FUNGSI KHUSUS
}

\author{
Penulis: \\ Emas Marlina, S.Pd., M.Pd \\ ISBN: \\ 978-623-6504-31-4 \\ Editor: \\ Saiful Anwar, S.Pd., S.E., M.Pd \\ Desain Sampul dan Tata Letak: \\ Agung Riqzi Wahyudi \\ Penerbit CV. Pena Persada \\ Redaksi :
}

J1. Gerilya No. 292 Purwokerto Selatan, Kab. Banyumas

Jawa Tengah

Email : penerbit.penapersada@gmail.com

Website : penapersada.com

Phone : (0281) 7771388

Anggota IKAPI

All right reserved

Cetakan pertama : 2020

Hak cipta dilindungi oleh undang-undang.

Dilarang memperbanyak karya tulis ini dalam bentuk dan cara apapun tanpa ijin penerbit 


\section{KATA PENGANTAR}

Puji dan syukur kehadirat Allah SWT atas segala anugerah dan rahmat-Nya, sehingga Buku Ajar Fungsi Khusus untuk tingkat Perguruan Tinggi ini dapat diselesaikan dengan baik.

Buku ajar Fungsi Khusus ini terdiri dari materi prasyarat yaitu Fungsi, Limit Fungsi, Turunan Fungsi, Integral dan materi inti yaitu Fungsi Gamma, Fungsi Beta, Deret Fourier, Fungsi Bessel, Fungsi Legendre, Fungsi Polinomial Hermite. Materi ini merupakan satu kesatuan materi yang dipelajari oleh mahasiswa secara menyeluruh dan tak terpisahkan selama satu semester karena merupakan satu kesatuan utuh dalam Capaian Kompetensi di Rencana Pembelajaran Semester.

Tujuan diterbitkannnya buku ini untuk membantu mahasiswa agar dapat menguasai konsep Fungsi Khusus. Di samping itu pula, buku ini dapat dijadikan acuan bagi dosen yang mengampu mata kuliah Fungsi Khusus. Isi buku ini memuat pendahuluan, penyajian materi, dan soal-soal latihan.

Pada kesempatan ini, penulis mengucapkan terimakasih kepada lembaga (Universitas Bale Bandung) yang telah memberikan kesempatan mengampu mata kuliah Fungsi Khusus. Kemudian, penulis tidak lupa ucapkan terimakasih kepada para guru-guru kami terdahulu yang telah membekali ilmu, sehingga dapat mengamalkan ilmu tersebut.

Buku ajar ini merupakan terbitan edisi pertama, yang tentunya masih butuh untuk disempurnakan. Oleh karena itu, saran dan masukkan oleh para pengguna sangat kami harapkan untuk kesempurnaan bahan ajar ini di masa yang akan datang.

Semoga bahan ajar ini bermanfaat bagi mahasiswa, dosen dan para pengguna lainnya.

Bandung, Juni 2020

Penulis 


\section{DAFTAR ISI}

KATA PENGANTAR ......................................................

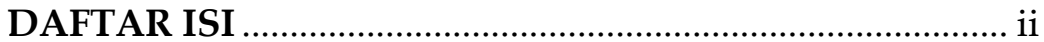

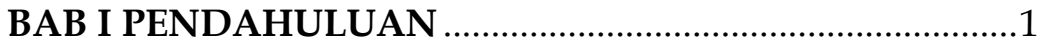

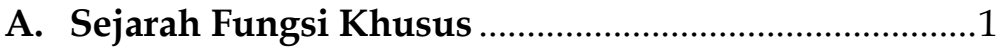

B. Kegunaan Fungsi Khusus ...........................................

C. Definisi Fungsi Khusus ..............................................

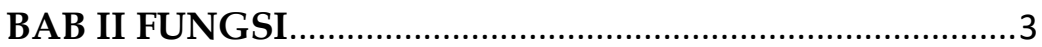

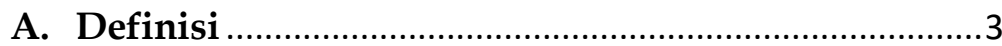

B. Notasi Fungsi ..........................................................

C. Daerah Asal Alami (Natural Domain) ......................... 4

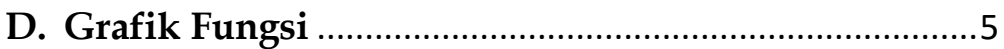

E. Operasi pada Fungsi ……………………...................

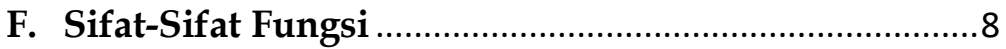

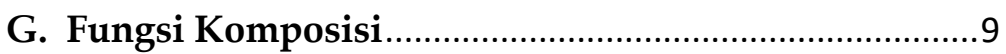

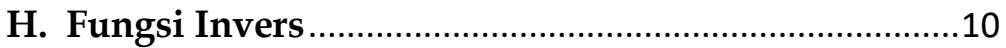

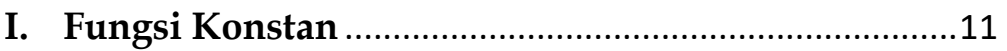

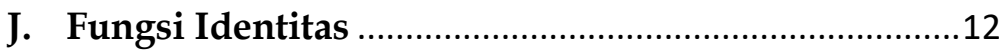

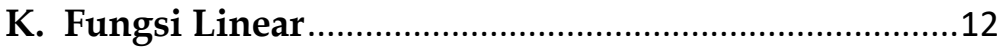

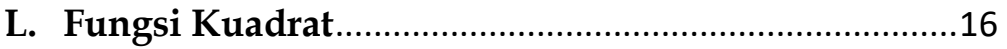

M. Fungsi Modulus (Nilai Mutlak)..................................19

N. Fungsi pada Interval Berbeda ...................................20

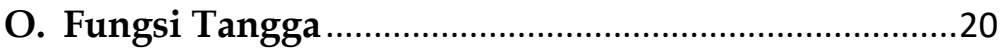

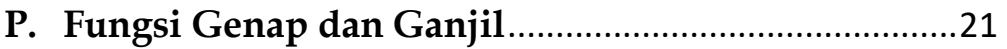

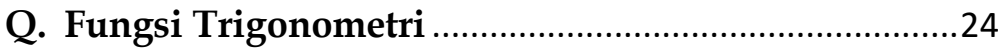




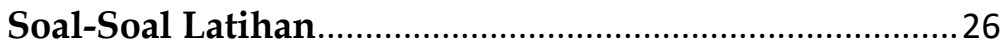

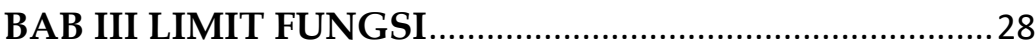

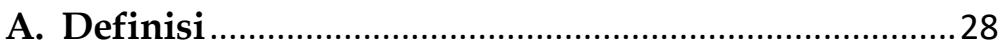

B. Menghitung Limit dengan Pemeriksaan (Substitusi) 29

C. Menghitung Limit dengan Perhitungan Aljabar .......29

D. Menghitung Limit dengan Mengalikan Sekawan.....30

E. Limit Fungsi Trigonometri .............................................30

F. Limit Kiri dan Limit Kanan.............................................31

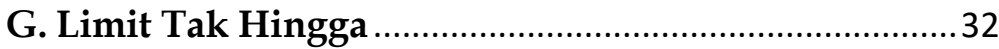

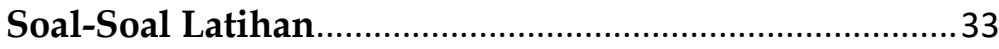

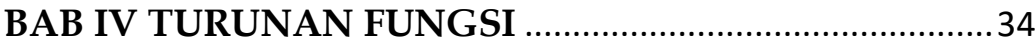

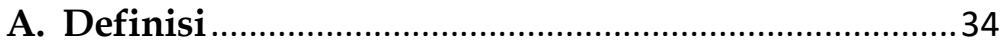

B. Rumus-Rumus Turunan Fungsi Aljabar.....................35

C. Rumus Turunan Fungsi Trigonometri .......................36

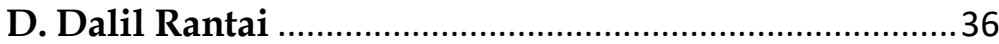

E. Nilai Stasioner dan Titik Stasioner ..............................37

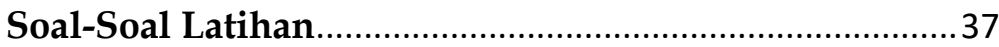

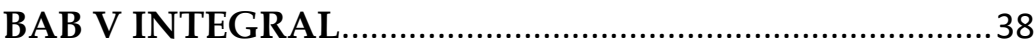

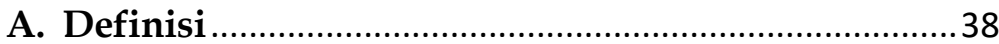

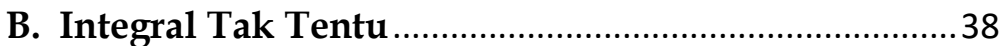

C. Integral Tak Tentu Fungsi Aljabar................................38

D. Integral Tak Tentu Fungsi Trigonometri ....................40

E. Integral Tak Tentu dengan Cara Substitusi ................40

F. Menghitung Integral Tentu dengan Teorema

Fundamental Integral Kalkulus.....................................41

G. Integral Tentu dengan Integral Parsial ....................... 42 
H. Integral pada Fungsi Eksponen Asli

I. Integral pada Fungsi Eksponen dan Fungsi Logaritma

Umum. .44

J. Integral Lipat Dua ................................................... 46

K. Integral Lipat Tiga .....................................................46

L. Integral Tak Wajar, Batas Tak Terhingga ...................47

Soal-Soal Latihan ............................................................50

BAB VI FUNGSI GAMMA............................................. 51

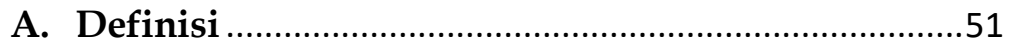

B. Rumus Rekursif Fungsi Gamma ...............................51

C. Fungsi Gamma Bilangan Bulat Positif.......................51

D. Fungsi Gamma Bilangan Pecahan Positif..................52

E. Fungsi Gamma Bilangan Pecahan Negatif .................53

F. Penggunaan Tabel Fungsi Gamma ............................54

G. Penggunaan Fungsi Gamma dalam Integral ..............55

H. Formula Penting Terkait Fungsi Gamma ..................57

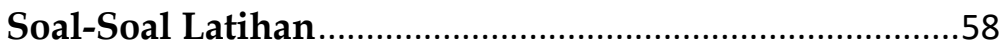

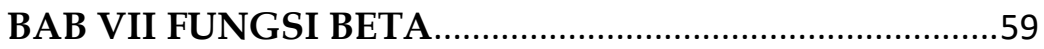

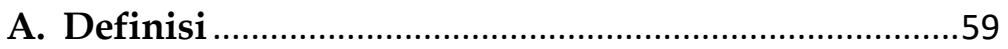

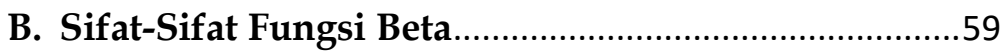

C. Hubungan Fungsi Beta dan Fungsi Gamma...............60

Soal-Soal Latihan..............................................................63

BAB VIII DERET FOURIER ................................................64

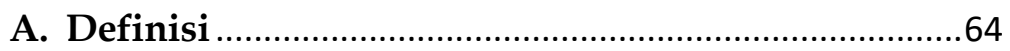

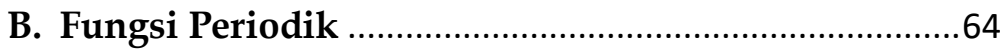

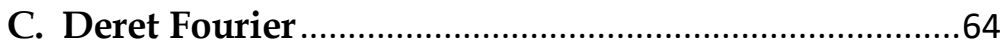


D. Fungsi Genap dan Fungsi Ganjil serta Fungsi Setengah Jangkauan....................................................69

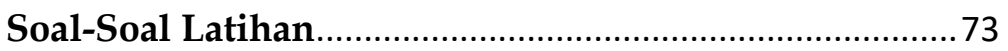

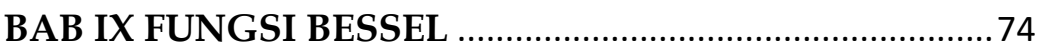

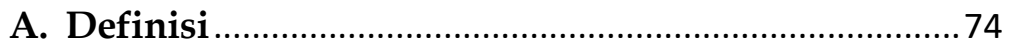

B. Jenis-Jenis Fungsi Bessel .......................................... 74

C. Fungsi Bessel Jenis Pertama ……............................... 75

D. Fungsi Bessel Jenis Kedua.........................................76

E. Fungsi Bessel Jenis Ketiga.........................................76

F. Persoalan Fungsi Bessel Jenis Pertama ...................... 77

G. Persoalan Fungsi Bessel Jenis Kedua ......................... 79

H. Persoalan Fungsi Bessel Jenis Ketiga ..........................79

I. Persamaan-Persamaan fungsi Bessel............................ 80

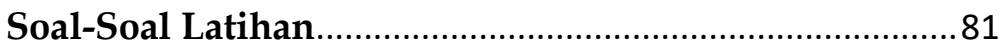

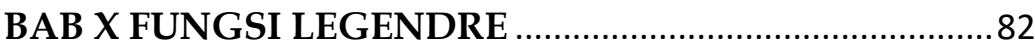

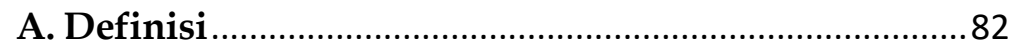

B. Rumus Menghitung Koefisien-Koefisien dari

Persamaan Diferensial Legendre ................................... 82

C. Penyelesaian Persamaan Legendre ............................. 83

Soal-Soal Latihan ........................................................... 85

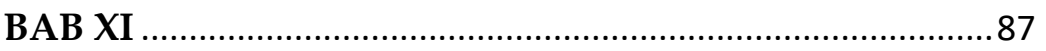

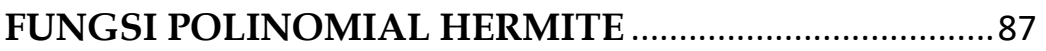

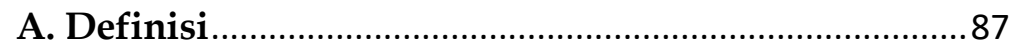

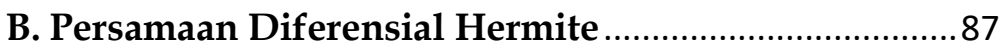

C. Rumus Rekursi Persamaan Hermite …........................ 87

D. Penyelesaian Persamaan Hermite .............................. 88 


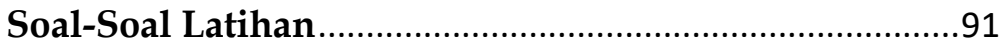

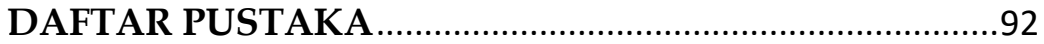

GLOSARIUM

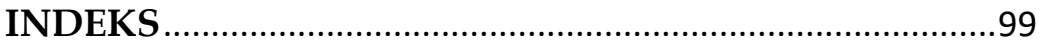

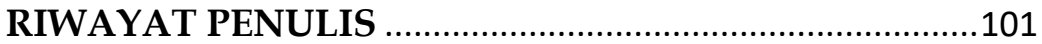




\section{BAB I PENDAHULUAN}

\section{A. Sejarah Fungsi Khusus}

Fungsi khusus dimulai dari zaman Babilonian yang asal mulanya berkembang secara sederhana, kemudian pada pertengahan abad, fungsi ini berupa trigonometri dan logaritma. Setelah muncul Kalkulus pada tahun 1600-an, mulailah terdapat fungsi tertentu hasil pengembangan diferensial dan integral. Sehingga tahun 1700-an Bernoulli berpendapat bahwa integral fungsi elementer akan menjadi fungsi elementer juga, akan tetapi bertentangan dengan pernyataan Leibniz bahwa tidak semua integral fungsi elementer dapat diselesaikan.

Contoh integral yang diungkapkan oleh Leibniz adalah $\int \frac{1}{x^{4}+a^{4}} d x$. Beberapa tahun kemudian muncullah integral eliptik (tidak analitik) dalam bentuk deret yang mengarah pada fungsi Bessel yaitu $\mathrm{F}(\varphi, k)=\int_{0}^{\varphi} \frac{1}{\sqrt{1-k^{2} \sin ^{2} \theta}} d \theta$.

Sekitar tahun 1720-an kemudian diperkenalkannya suatu standarisasi fungsi khusus oleh Euler. Dia menenemukan fungsi Gamma sebagai kelanjutan faktorial dan mendefinisikan fungsi Bessel untuk penelitian drum sikular, mengembangkan integral elliptik dan sebagainya. Pada penghujung tahun 1700-an muncul beberapa fungsi khusus di antaranya ialah fungsi Legendre yang berkaitan dengan teori potensial dan mekanika benda langit. Pada tahun tersebut para ahli Matematika tidak berhenti dalam menemukan sesuatu hal yang baru, sehingga di tahun berikutnya 1800-an ditemukanlah beberapa fungsi khusus lainnya di antaranya adalah muncul fungsi periodik tepatnya pada tahun 1820-an.

Selain dari fungsi periodik, beberapa tahun kemudian muncul analisis harmonik, beberapa polinomial orthogonal seperti Hermite Laguerre dan sebagainya. Dikarenakan pada tahun 1800an hampir semua fungsi khusus bermunculan, sehingga Gauss menyatukan semua fungsi khusus, dan muncullah fungsi Gauss Hipergeometrik. 
Seiring waktu fungsi khusus berkembang hingga saat ini, pada ilmu Fisika selalu memberikan energi baru dengan memanfaatkan mekanika, teori elastisitas, dan teori elektromagnetik. Sehingga pada tahun 1920-an dengan kelahiran mekanika kuantum banyak problem berkaitan dengan polinomial Leguerre dan Hermite. Adanya teori hamburan ini, maka diperlukan fungsi-fungsi khusus pada mekanika kuantum.

\section{B. Kegunaan Fungsi Khusus}

Penggunaan fungsi khusus di antaranya adalah sebagai berikut:

1. Fungsi Gamma dan Beta sering muncul pada pemecahan persamaan diferensial, proses Fisika, perpindahan panas, gesekan sumber bunyi, rambatan gelombang, potensial gaya, persamaan gelombang, mekanika kuantum dan lainnya.

2. Kelahiran mekanika kuantum banyak problem berkaitan dengan polinomial Leguerre dan Hermite.

Penggunaan fungsi khusus banyak digunakan dalam Kalkulus, Probabilitas Mekanika Statistik, Peluang, Kombinatorika, Fisika dan Tehnik.

\section{Definisi Fungsi Khusus}

Fungsi khusus berasal dari kata "fungsi" dan "khusus". Fungsi adalah suatu relasi yang mempunyai ciri-ciri tertentu didefinisikan dengan fungsi $f$ dari $\mathrm{A}$ ke $\mathrm{B}$ adalah relasi khusus yang memasangkan tiap-tiap anggota A dengan tepat satu anggota B sedangkan khusus artinya memiliki ciri khas tersendiri. Fungsi khusus adalah fungsi yang memenuhi persamaan diferensial tak homogen. Sehingga fungsi khusus merupakan penyelesaian khusus dalam menyelesaikan permasalahan diferensial. Pokok bahasan yang akan kita bahas pada fungsi khusus adalah fungsi Gamma, fungsi Beta, deret Fourier, fungsi Bessel, fungsi Legendre, fungsi polinomial Hermite. 


\section{BAB II FUNGSI}

\section{A. Definisi}

Fungsi disebut pula pemetaan (mapping) adalah suatu relasi yang mempunyai ciri-ciri tertentu. Dengan demikian setiap fungsi adalah relasi, tetapi tidak setiap relasi merupakan fungsi. Ciri-ciri relasi yang merupakan fungsi adalah semua unsur pada daerah asal harus direlasikan dan relasinya tunggal (unik). Setiap unsur di daerah fungsi harus direlasikan dengan tepat satu unsur di daerah hasil. Untuk lebih jelas perhatikan gambar di bawah ini.

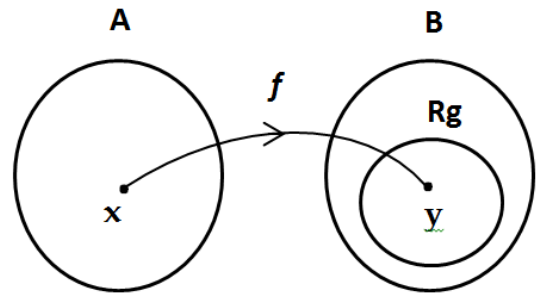

Himpunan A disebut sebagai daerah asal (Domain) dan himpunan B disebut daerah kawan (Kodomain). Himpunan A direlasikan tepat satu unsur di himpunan B atau daerah hasil (Range). Himpunan semua anggota B yang merupakan peta atau bayangan dari unsur A disebut himpunan nilai fungsi $f$ dan disebut jelajah fungsi $f$.

Definisi fungsi:

Fungsi $f$ dari A ke B adalah relasi khusus yang memasangkan tiaptiap anggota A dengan tepat satu anggota $B$.

Contoh fungsi:

A

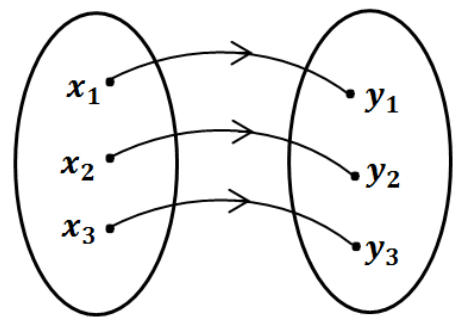

A

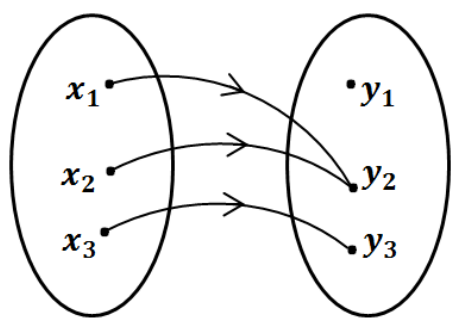


Contoh bukan fungsi:

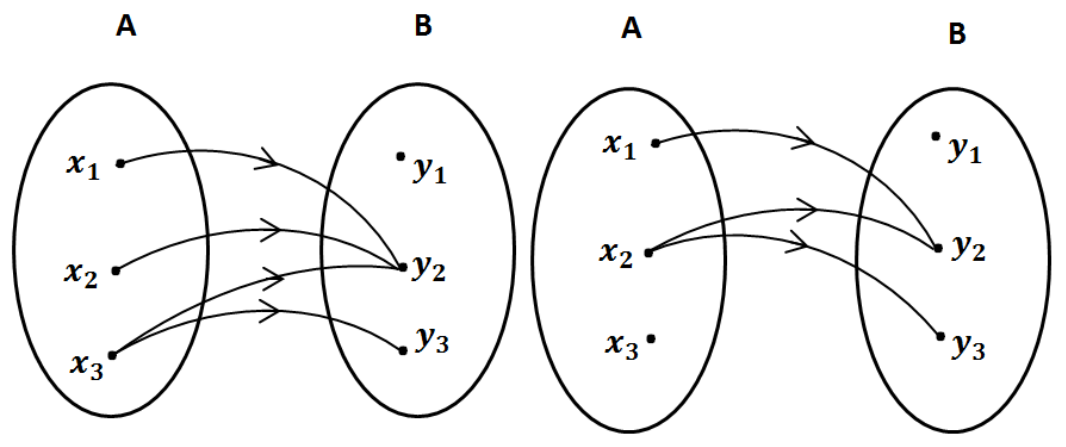

\section{B. Notasi Fungsi}

Untuk memberi nama fungsi dipakai huruf $f(x), g(x)$ atau $F(x)$. Maka $f(x)$ dibaca $f$ dari $x$ atau $f$ pada $x$. Notasi fungsi $f$ dari A ke B adalah $f:$ A $\rightarrow$ B.

Dalam notasi Matematika, fungsi yang memetakan setiap anggota A ke anggota $B$ adalah:

$f: \mathrm{A} \rightarrow \mathrm{B} \leftrightarrow \forall x \in \mathrm{A}, \exists y \in \mathrm{B}, \mathrm{y}$ unik $\ni \mathrm{y}=f(\mathrm{x})$.

Contoh:

$$
\begin{array}{ll}
f(x) & =x^{3}-4 \\
f(2) & =(2)^{3}-4=4 \\
f(-1) & =(-1)^{3}-4=-5 \\
f(a+h) & =(a+h)^{3}-4 \\
& =a^{3}+3 a^{2} h+3 a h^{2}+h^{3}-4
\end{array}
$$

\section{Daerah Asal Alami (Natural Domain)}

Jika sebuah fungsi daerah asalnya tidak disebutkan, maka daerah asalnya adalah himpunan bilangan real terbesar sehingga aturan fungsi ada maknanya dan memberikan nilai bilangan real.

\section{Contoh:}

Cari daerah asal mula (natural) untuk:
a) $f(x)=\frac{1}{(x-3)}$
b) $g(t)=\sqrt{9-t^{2}}$
c) $f(x)=\frac{4}{x-3}$
d) $f(x)=\frac{1}{x^{2}-2 x-3}$
e) $f(x)=\sqrt{4-x^{2}}$
f) $f(x)=\frac{1}{\sqrt{x^{2}-x-12}}$ 
Penyelesaian:

a. Daerah asal mula untuk $f$ adalah $\{x \in \mathbb{R}: x \neq 3\}$. Ini dibaca "himpunan $x$ dalam $\mathbb{R}$ (bilangan real) sedemikian sehingga $x$ tidak sama dengan 3 ". Kita kecualikan 3 untuk menghindari pembagian oleh 0 .

b. Di sini kita harus membatasi $t$ sedemikian sehingga $9-t^{2} \geq 0$ dengan tujuan menghindari nilai-nilai tak real untuk $\sqrt{9-t^{2}}$. Ini dicapai dengan mensyaratkan bahwa $|t| \leq 3$.

Sehingga, daerah asal mula adalah $\{x \in \mathbb{R}:|t| \leq 3\}$. Dalam cara penulisan selang, kita dapat menulis daerah asal sebagai $[-3,3]$.

c. $f(x)=\frac{4}{x-3}$, pada fungsi rasional penyebut tidak boleh nol agar terdefinisi, sehingga $x-3 \neq 0$ atau $x \neq 3$.

Jadi derah asal alami fungsi adalah $D_{f}=\{x \mid x \in R$ dan $x \neq 3\}$

d. $(f(x))=\frac{1}{x^{2}-2 x-3}$, pada fungsi rasional penyebut tidak boleh nol agar terdefinisi, maka $x^{2}-2 x-3 \neq 0$

sehingga $(x-3)(x+1) \neq 0 \quad x \neq 3$ atau $x \neq-1$.

Jadi, derah asal alami fungsi adalah,

$D_{f}=\{x \mid x \in R, x \neq 3$ atau $x \neq-1\}$

e. $(f(x))=\sqrt{4-x^{2}}$, fungsi irasional terdefinisi jika bagian di bawah tanda akar positif atau nol, maka $4-x^{2} \geq 0$ atau $x^{2}-4 \leq 0$ difaktorkan $(x+2)(x-2) \leq 0$ atau $-2 \leq x \leq 2$.

Jadi, $D_{f}=\{x \mid x \in R,-2 \leq x \leq 2\}$

f. Diketahui $(f(x))=\frac{1}{\sqrt{x^{2}-x-12}}$, fungsi pecahan irasional jika bagian penyebut

$x^{2}-x-12>0$ atau $(x-4)(x+3)>0$

maka $x<3$ atau $x>4$.

Jadi, $D_{f}=\{x \mid x \in R,<3$ atau $x>4\}$.

\section{Grafik Fungsi}

Jika $f$ suatu fungsi yang memetakan setiap anggota A tepat ke anggota $\mathrm{B}(f: \mathrm{A} \rightarrow \mathrm{B})$, maka grafik fungsi tersebut adalah himpunan yang terdiri dari semua pasangan berurutan dengan a $\epsilon$ A sebagai anggota pertama dan bayangannya (peta) adalah $f$ (a) sebagai anggota kedua.

$$
f:\{(a, b) \mid a \in A, b=f(a)\}
$$


Contoh:

1. $\mathrm{A}=\{1,2,3,4,5\}$ dan $\mathrm{R}=\{$ himpunan bilangan real $\}$.

$f: \mathrm{A} \rightarrow \mathrm{R}$ didefinisikan dengan $f(x)=x+3$, maka tentukan grafiknya?

Penyelesaian:

Untuk $x=1$ maka $f(1)=1+3=4$, sehingga titik yang diperoleh $\{1,4\}$

Untuk $x=2$ maka $f(2)=2+3=5$, sehingga titik yang diperoleh $\{2,5\}$

Untuk $x=3$ maka $f(3)=3+3=6$, sehingga titik yang diperoleh $\{3,6\}$ Untuk $x=4$ maka $f(4)=4+3=7$, sehingga titik yang diperoleh $\{4,7\}$ Untuk $x=5$ maka $f(5)=5+3=8$, sehingga titik yang diperoleh $\{5,8\}$. Jadi, grafiknya adalah $\{(1,4),(2,5),(3,3),(4,7),(5,8)\}$.

2. Jika $f: \mathrm{A} \rightarrow \mathrm{B}$ dengan $\mathrm{A}=\{x \mid-2 \leq x \leq 2, x$ himpunan bilangan real\}.

Gambarlah grafiknya!
a. $f(x)=2 x-7$
b. $f(x)=x^{2}$

Penyelesaian:

a. $f(x)=2 x-7$

\begin{tabular}{|c|c|c|c|c|c|}
\hline $\mathrm{X}$ & -2 & -1 & 0 & 1 & 2 \\
\hline $\mathrm{Y}$ & -11 & -9 & -7 & -5 & -3 \\
\hline
\end{tabular}

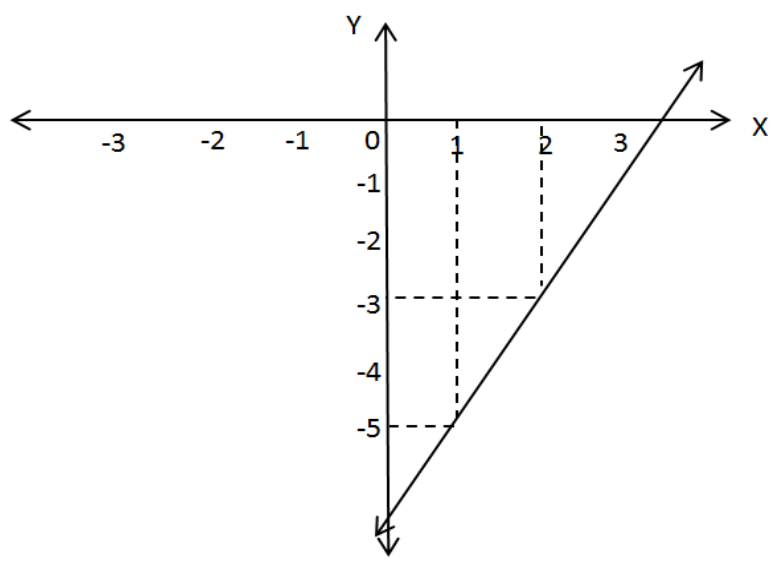


b. $f(x)=x^{2}$

\begin{tabular}{|c|c|c|c|c|c|}
\hline $\mathrm{X}$ & -2 & -1 & 0 & 1 & 2 \\
\hline $\mathrm{Y}$ & 4 & 1 & 0 & 1 & 4 \\
\hline
\end{tabular}

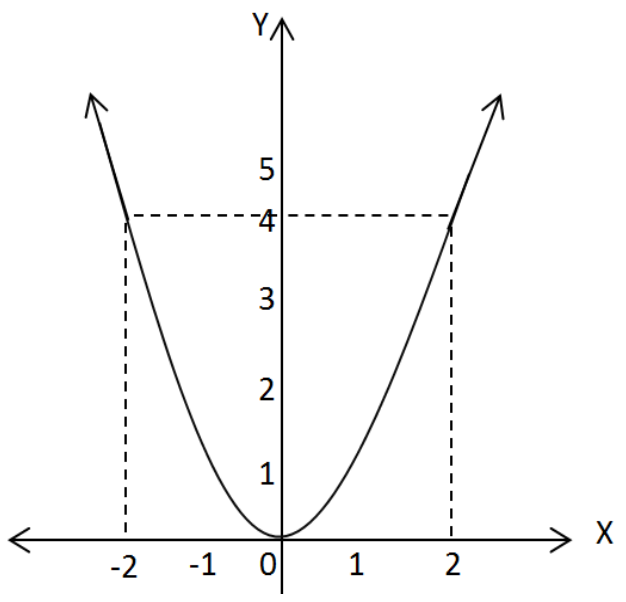

\section{E. Operasi pada Fungsi}

Jika $f$ dan $g$ dua fungsi maka jumlah $f+g$, selisih $f-g$, hasil kali $f g$, hasil bagi $\frac{f}{g}$ dan perpangkatan $f^{n}$ adalah sebagai berikut.

1. $(f+g)(x)=f(x)+g(x)$

2. $(f-g)(x)=f(x)-g(x)$

3. $(f g)(x)=f(x) g(x)$

4. $\left(\frac{f}{g}\right)(x) \quad=\frac{f(x)}{g(x)}$, asalkan $g(x)=0$

Contoh :

Jika $f(x)=x^{2}-2 x$ dan $g(x)=x-1$, tentukan:
a. $f+g$
b. $f-g$
c. $\frac{f}{g}$
d. $f^{2}$

Penyelesaian:
a. $f+g=\left(x^{2}-2 x\right)+(x-1)=\left(x^{2}-x-1\right)$
b. $f-g=\left(x^{2}-2 x\right)-(x-1)=\left(x^{2}-3 x+1\right)$
c. $\frac{f}{g} \quad=\frac{\left(x^{2}-2 x\right)}{(x-1)}=\frac{x(x-2)}{(x-1)}$
d. $f^{2}=\left(x^{2}-2 x\right)^{2}=x^{4}-4 x^{2}+4 x^{2}=x^{4}$ 


\section{F. Sifat-Sifat Fungsi}

Sifat-sifat fungsi adalah sebagai berikut:

1. Fungsi Injektif

Fungsi injektif adalah fungsi satu-satu, dengan setiap anggota di B mempunyai pasangan tepat satu di A.

Definisi: Jika a dan $\mathrm{b}$ adalah himpunan $\mathrm{A}$, maka $f(\mathrm{a}) \neq f(\mathrm{~b})$ bilamana $\mathrm{a} \neq \mathrm{b}$. jika $f(\mathrm{a})=f(\mathrm{~b})$ maka implikasinya adalah $\mathrm{a}=\mathrm{b}$.

Contoh:

A

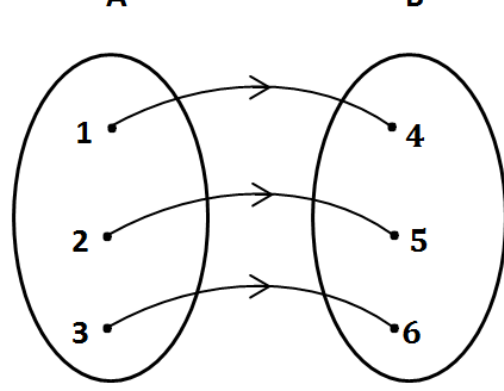

Fungsi Injektif
A

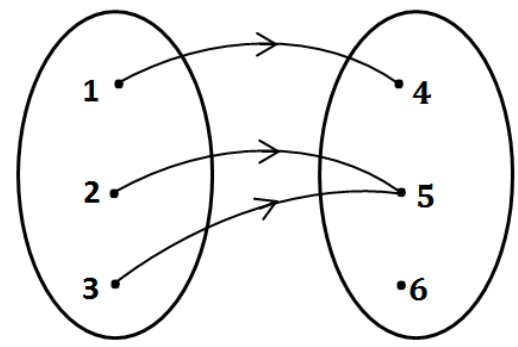

Bukan Fungsi Injektif

\section{Fungsi Surjektif}

Fungsi surjektif adalah fungsi onto yang memasangkan A ke $B$ dengan daerah hasil $f(\mathrm{~A})$ dari fungsi $f$ adalah himpunan bagian dari $\mathrm{B}$, atau $f(\mathrm{~A}) \subset \mathrm{B}$. Apabila $f(\mathrm{~A})=\mathrm{B}$, setiap anggota di $\mathrm{B}$ merupakan pasangan sekurang-kurangnya satu anggota di $\mathrm{A}$ atau dengan kata lain anggota $\mathrm{B}$ berpasangan satu atau lebih dengan anggota A.

Definisi: $f$ surjektif jika dan hanya jika untuk setiap $\mathrm{b} \in \mathrm{B}$ ada $\mathrm{a} \in \mathrm{A}$ sedemikian hingga $f(a)=b$.

Contoh fungsi surjektif:

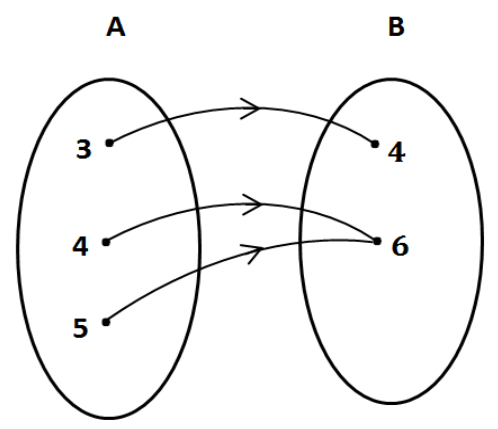


3. Fungsi Bijektif (Korespondesi Satu-Satu)

Fungsi bijektif adalah fungsi yang injektif dan surjektif sekaligus, A dan B berada dalam korespondensi satu-satu.

Contoh:

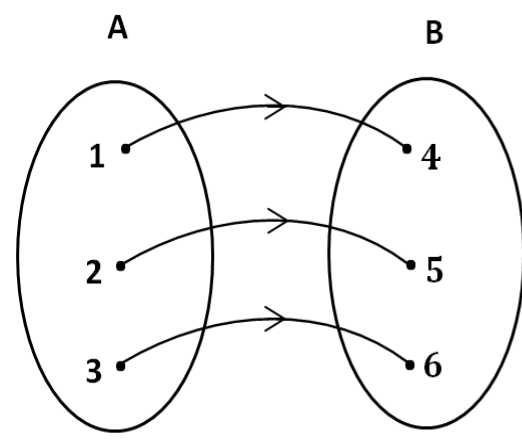

Fungsi Bijektif
A B

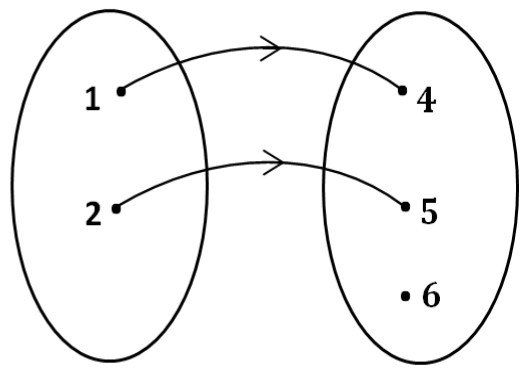

BukanFungsi Bijektif

\section{G. Fungsi Komposisi}

Jika fungsi $f: \mathrm{A} \rightarrow \mathrm{B}$, fungsi $g: \mathrm{B} \rightarrow \mathrm{C}$, maka fungsi $h: \mathrm{A} \rightarrow \mathrm{C}$ merupakan fungsi komposisi $f$ dan $g$.

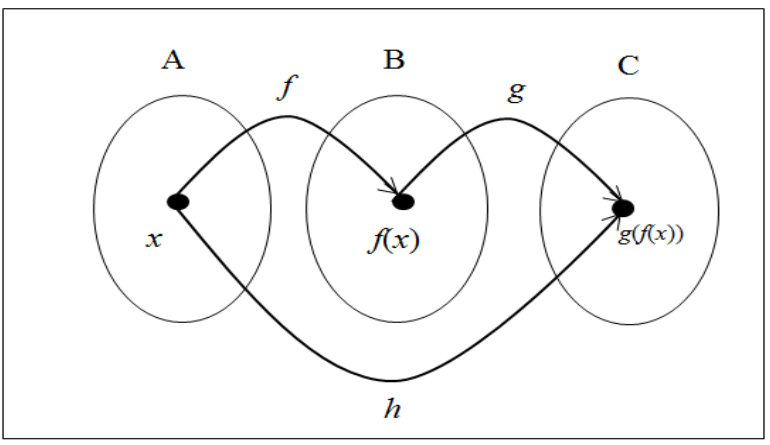

Sehingga $h(x)=\left(g^{\circ} f\right)(x)=g(f(x))$ dengan ketentuan wilayah hasil $f=$ daerah asal fungsi $g\left(\mathrm{~W}_{\mathrm{f}}=\mathrm{D}_{\mathrm{g}}\right)$ dan untuk $\left(f^{\circ} g\right)(x)=f(g(x))$ dengan ketentuan wilayah hasil $g=$ daerah asal fungsi $g\left(\mathrm{~W}_{\mathrm{g}}=\mathrm{D}_{f}\right)$.

Jika $f$ dan $g$ dua fungsi maka dengan daerah asal $g$ merupakan daerah hasil $f$ maka komposisi $g^{\circ} f$ memenuhi $\left(g^{\circ} f\right)=g(f(x))$. 
Contoh:

Jika $f(x)=x^{2}-2 x$ dan $g(x)=x-1$,

Tentukan $g^{\circ} f$ dan $f^{\circ} g$

Penyelesaian:

$$
\begin{aligned}
\left(g^{\circ} f\right)(x) & =g(f(x)) \\
& =g\left(x^{2}-2 x\right) \\
& =x^{2}-2 x-1 \\
\left(f^{\circ} g\right)(x) & =f(g(x)) \\
& =f(x-1) \\
& =(x-1)^{2}-2(x-1) \\
& =x^{2}-2 x-1-2 x+2 \\
& =x^{2}-4 x+1
\end{aligned}
$$

\section{H. Fungsi Invers}

Jika fungsi $f: \mathrm{A} \rightarrow \mathrm{B}$ dan misalkan $\mathrm{b} \in \mathrm{B}$, maka invers $\mathrm{b}$ terhadap fungs $f\left\{f^{-1}(b)\right\}$ adalah himpunan semua anggota A yang pemetaannya adalah $b$.

$$
f^{-1}(\mathrm{~b})=\{x \mid x \in \mathrm{A}, f(x)=\mathrm{b}\}
$$

Mencari rumus fungsi:

Jika $f^{-1}$ adalah invers dari $f \operatorname{dan} f(x)=y$, maka $f^{-1}(y)=x$.

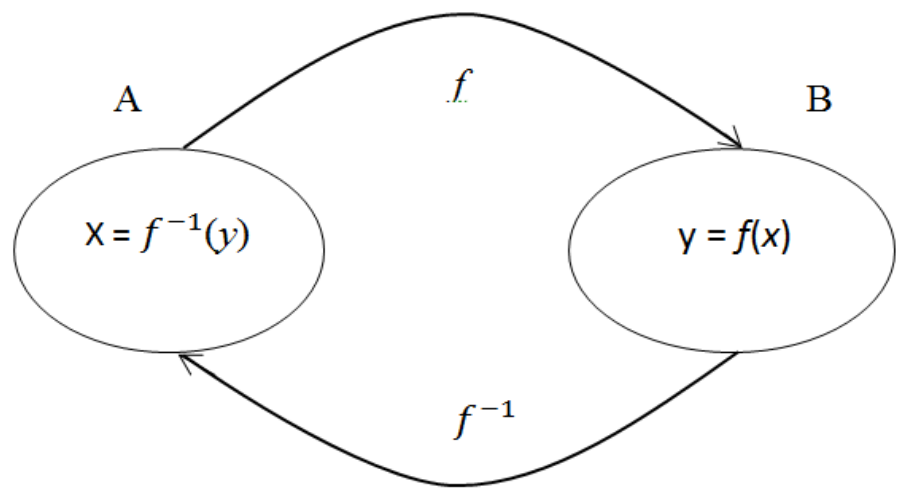

Contoh:

Tentukan inves fungsi dari,
a. $f(x)=3 x+2$
b. $f(x)=\frac{x-1}{x-3}$ 